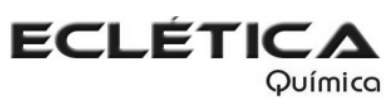

www.scielo.br/eq

www.ecletica.iq.unesp.br

Volume 33, número 2, 2008

\title{
Spectrophotometric flow injection procedure to indirect determination of paracetamol in pharmaceutical formulations using o-tolidine as reagent
}

\author{
O. Fatibello-Filho*, H. J. Vieira \\ Departamento de Química, Centro de Ciências Exatas e de Tecnologia \\ Universidade Federal de São Carlos, São Carlos, Brasil. \\ *bello@dq.ufscar.br
}

\begin{abstract}
A spectrophotometric flow injection method for the determination of paracetamol in pharmaceutical formulations is proposed. The procedure was based on the oxidation of paracetamol by sodium hypochloride and the determination of the excess of this oxidant using $o$-tolidine dichloride as chromogenic reagent at $430 \mathrm{~nm}$. The analytical curve was linear in the paracetamol concentration range from $8.50 \times 10^{-6}$ to $2.51 \times 10^{-4} \mathrm{~mol} \mathrm{~L}^{-1}$ with a detection limit of $5.0 \times 10^{-6} \mathrm{~mol} \mathrm{~L}^{-1}$. The relative standard deviation was smaller than $1.2 \%$ for $1.20 \times 10^{-4} \mathrm{~mol} \mathrm{~L}^{-1}$ paracetamol solution $(\mathrm{n}=10)$. The results obtained for paracetamol in pharmaceutical formulations using the proposed flow injection method and those obtained using a USP Pharmacopoeia method are in agreement at the $95 \%$ confidence level.
\end{abstract}

Keywords: paracetamol; pharmaceutical analysis; flow injection analysis; spectrophotometry.

\section{Introduction}

Paracetamol (4-acetoaminophen) has mild analgesic and antipyretic properties and is, along with acetylsalicylic acid, one of the most popular analgesic agents. The administration of this drug with caffeine yields analgesic effects significantly greater than that of paracetamol alone $[1,2]$.

Several methods have been employed for the spectrophotometric determination of this drug in combined dosage forms [3-7]. Chromatographic methods have been proposed for the simultaneous determination of paracetamol and other active principles [8-10], Fluorescence spectroscopy methods were also described [11, 12], however those methods are time-consuming and use expensive equipments. Electroanalytical methods were proposed to paracetamol determi- nation in pharmaceutical formulations using carbon paste electrode [13-15].

Flow injection systems are useful tools for the automation, miniaturization and simplification of analytical processes. These procedures permit obtain results faster and accurate than batch procedures [16].

Flow injection spectrophotometric systems with spectrophotometric detection were described using nitrite as reactant [17-19]. Other spectrophotometric flow injection methods based on reaction of paracetamol to produce a indophenol dye [20-24] and systems with solid phase UV spectrophotometric detection [25-28] have been described for paracetamol determination in pharmaceutical formulations. Flow procedures with chemiluminescence detection were described using luminol based reaction [29, 30] 
and another method employed the oxidation of tris(2,2'-bipyridyl)ruthenium(II) by potassium permanganate [31]. A Fourier transformed infrared (FTIR) method based on the detection of products formed in the alkaline hydrolysis of paracetamol was also proposed in the literature [32]. A flow-injection method with spectrofluorimetric detection to determine paracetamol based on its oxidation with hexacyanoferrate(III) was reported [33]. Different techniques for quantification of paracetamol in pharmaceuticals were evaluated in a recent review [34].

The major substances found as products of chlorination of paracetamol were 1,4-benzoquinone and N-acetyl-p-benzoquinoneimine (NAPQI). Other products that were identified included the chloro-4-acetamidophenol and dichloro-4-acetamidopheno [35].

In this article a fast, simple and accurate flow injection procedure with spectrophotometric detection to determine paracetamol in pharmaceutical products exploiting the reaction between paracetamol and hypochlorite is proposed. In this method the excess of oxidant was determined spectrophotometrically using $o$-tolidine (3,3'-dimethylbenzidine) as reagent at a wavelength of $430 \mathrm{~nm}$.

\section{Experimental}

\section{Reagents and solutions}

All experiments were performed with chemicals of analytical grade: paracetamol (Sigma), o-tolidine hydrochloride (Merck), sodium hypochlorite (Vetec, São Paulo, Brazil) and sodium borate (Synth), were used as received. All solutions were prepared with desionized water from a Millipore (Bedford, MA) Milli-Q system (model UV Plus Ultra-Low Organics Water).

A $8.53 \times 10^{-3} \mathrm{~mol} \mathrm{~L}^{-1}$ paracetamol stock solution was prepared dissolving $129 \mathrm{mg}$ of this drug with desionized water in a $100.0 \mathrm{~mL}$ calibrated flask and reference solutions were prepared by appropriate stock solution dilution with desionized water.

A $4.31 \times 10^{-3} \mathrm{~mol} \mathrm{~L}^{-1} o$-tolidine dichloride (3,3'-Dimethyl-(1,1'-biphenyl)-4,4'-diamine) stock solution was prepared dissolving $123.0 \mathrm{mg}$ of the reagent with desionized water in a 100.0
$\mathrm{mL}$ calibrated flask. An additional dilution was performed in $250.0 \mathrm{~mL}$ calibrated flask with 0.19 mol L-1 $\mathrm{HCl}$ solution to obtain a $9.8 \times 10^{-5} \mathrm{~mol} \mathrm{~L}^{-}$ ${ }^{1} \mathrm{o}$-tolidine work solution.

A sodium hypochlorite stock solution was prepared diluting $2.0 \mathrm{~mL}$ of the concentrated solution in a $250.0 \mathrm{~mL}$ calibrated flask with a $1.00 \times 10^{-}$ $2 \mathrm{~mol} \mathrm{~L}^{-1}$ borate buffer solution ( $\mathrm{pH} 9.0$ ). An additional dilution was performed transferring $2.0 \mathrm{~mL}$ of this solution to a $250.0 \mathrm{~mL}$ calibrated flask and the volume was made up with a $1.00 \times 10^{-2} \mathrm{~mol} \mathrm{~L}^{-1}$ borate buffer solution. This stock solution was standardized using a titrimetric method.

A $0.19 \mathrm{~mol} \mathrm{~L}^{-1} \mathrm{HCl}$ solution was prepared by dilution of $8.0 \mathrm{~mL} \mathrm{HCl}$ (Merck) in $500.0 \mathrm{~mL}$ and this solution was standardized with a 0.100 mol L-1 $\mathrm{NaOH}$ standard solution.

Brazilian pharmaceutical products such as, Cibalena $^{\circledR}$ (Novartis Indústria Farmacêutica, S.B. dos Campos, SP); Tylenol 500 ${ }^{\circledR}$, Tylenol $750^{\circledR}$ and Tylenol DC ${ }^{\circledR}$ (Janssen-Cilag Farmacêutica, São José dos Campos, SP); Tyramol $750^{\circledR}$ (Laboratórios Farmacêuticos Caresse, São Paulo); Paracetamol 500 ${ }^{\circledR}$ (EMS Sigma Pharma, Hortolândia, São Paulo); Resfry ${ }^{\circledR}$ (Laboratório Neo Química Com. Ind. Ltda, Anápolis, GO); Paracetamol ${ }^{\circledR}$ (Eurofarma Laboratórios Ltda, São Paulo) were purchased from a local drugstore and analyzed using the proposed flow method and a comparative USP Pharmacopoeial procedure [36].

\section{Apparatus}

Flow injection spectrophotometric measurements were carried out using a Femto 485 spectrophotometer (São Paulo, Brazil) equipped with a Hellma ${ }^{\circledR}$ flow cell (path length $10 \mathrm{~mm}$, inner volume $18 \mu \mathrm{L}, \mathrm{NY}$, USA) connected to a Cole-Parmer (Chicago, Il, USA) model 1202-0000 two-channel strip-chart recorder. An Ismatec ${ }^{\circledR}$ IPC-12 peristaltic pump (Zurich, Switzerland) supplied with Tygon ${ }^{\circledR}$ tubing and an injector-commutator were used throughout [37]. The flow manifold was constructed with polyethylene tubing $(0.8 \mathrm{~mm}$ i.d.).

\section{Preparation of pharmaceutical samples}

The contents of tablets or sachets were weighed and powered in a mortar. Mass varying from 120.0 to $156.0 \mathrm{mg}$ of paracetamol were accurately weighed and dissolved with $30 \mathrm{~mL}$ of 
desionized water in $50.0 \mathrm{~mL}$ calibrated flask. These solutions were gently shaken by $10 \mathrm{~min}$ and the volume was completed with desionized water. Another dilution from theses solutions were performed using aliquots varying from $195-200 \mu \mathrm{L}$ to obtain final concentrations of $c a .1 .10 \times 10^{-4} \mathrm{~mol} \mathrm{~L}$ 1 in $25.0 \mathrm{~mL}$ calibrated flask with desionized water.

For the liquid formulation, an accurate aliquot of $200 \mu \mathrm{L}$ was transferred to a $50.0 \mathrm{~mL}$ calibrated flask and the volume was completed with desionized water. The final concentration obtained was $c a 1.1 \times 10^{-4} \mathrm{~mol} \mathrm{~L}^{-1}$.

\section{Flow injection procedure}

In the flow injection manifold, shown in the Figure 1, when the all solutions were propelled by peristaltic pump, a baseline was generated by reaction between the sodium hypochlorite and the $o$ tolidine streams and continuously monitored by spectrophotometer at $430 \mathrm{~nm}$ (equation 1, Scheme 1). The sample or standard solutions containing paracetamol $(80 \mathrm{~cm} ; 400 \mu \mathrm{L})$ were injected with the aid of injector-commutator into desionized carrier stream $\left(\mathrm{C} ; 2.2 \mathrm{~mL} \mathrm{~min}^{-1}\right)$ and merges downstream with $9.4 \times 10^{-5} \mathrm{~mol} \mathrm{~L}^{-1}$ hypochlorite solution in $1.00 \times 10^{-2} \mathrm{~mol} \mathrm{~L}^{-1}$ borate buffer solution ( $\mathrm{pH} 9.0$ ) $\left(\mathrm{R}_{1} ; 0.9 \mathrm{~mL} \mathrm{~min}^{-1}\right)$ in the confluence point $X$ promoting the consumption of $\mathrm{ClO}^{-}$(equation 2, Scheme 1). After the reaction coil $\mathrm{RC}_{1}(75 \mathrm{~cm})$, the dispersed sample zone merges with a colorless $9.8 \times 10^{-5} \mathrm{~mol} \mathrm{~L}^{-1} o$-tolidine solution in $0.20 \mathrm{~mol} \mathrm{~L}^{-}$ ${ }^{1} \mathrm{HCl}$ solution at confluence point $Y\left(\mathrm{R}_{2} ; 1.6 \mathrm{~mL}\right.$ $\mathrm{min}^{-1}$ ) where the yellow reaction product was monitored spectrophotometrically. In this way, the decrease of absorbance ( $\Delta \mathrm{A})$ caused by hypochlo- rite consumption was proportional to concentration of paracetamol in the solution injected.

\section{Comparative procedure}

To validation of proposed flow injection method the results obtained were compared with those results obtained using a comparative USP Pharmacopoeia procedure [36]. This procedure is based in the intrinsic absorption of paracetamol in UV region $(\lambda=244 \mathrm{~nm})$. For the determination of paracetamol, the samples and reference solutions were diluted in sodium hydroxide solution and the concentration of paracetamol was performed by interpolation in an analytical curve.

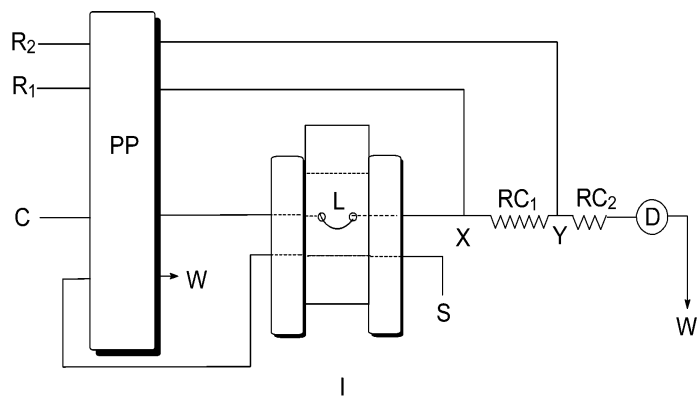

Figure 1. Flow injection spectrophotometric method for paracetamol determination in pharmaceutical products. PP: peristaltic pump; L: sample loop $(400 \mu \mathrm{L})$; C: carrier $\left(\mathrm{H}_{2} \mathrm{O} ; 2.2 \mathrm{~mL} \mathrm{~min}^{-1}\right)$; $\mathrm{R}_{1}$ : $9.4 \times 10^{-5} \mathrm{~mol} \mathrm{~L}^{-1}$ hypochlorite solution $\left(0.9 \mathrm{~mL} \mathrm{~min}^{-}\right.$ $\left.{ }^{1}\right) ; \mathrm{R}_{2}: 9.8 \times 10^{-5} \mathrm{~mol} \mathrm{~L}^{-1} o$-tolidine solution $(1.6 \mathrm{~mL}$ $\left.\min ^{-1}\right)$; I: injector-commutator $(80 \mathrm{~cm}$; $400 \mu \mathrm{L})$; $\mathrm{RC}_{1}$ and $\mathrm{RC}_{2}$ : reaction coil $(75 \mathrm{~cm}$, both); D: spectrophotometer $(\lambda=430 \mathrm{~nm}) ; \mathrm{X}$ and $\mathrm{Y}$ : confluence point and $\mathrm{W}$ : waste. The distance between the injector I and X confluence point was $5 \mathrm{~cm}$.
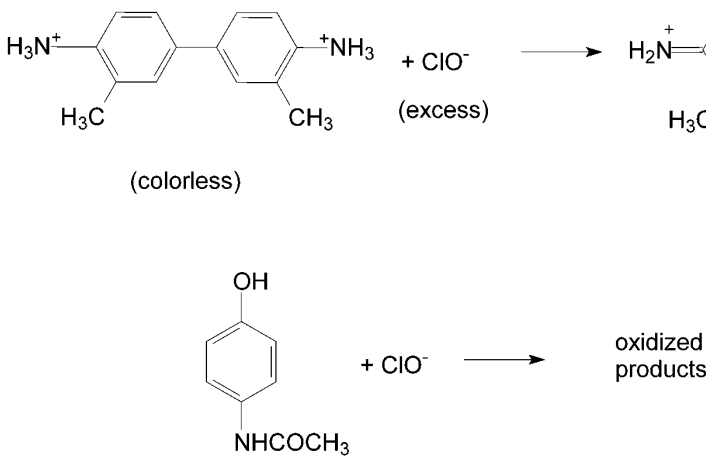

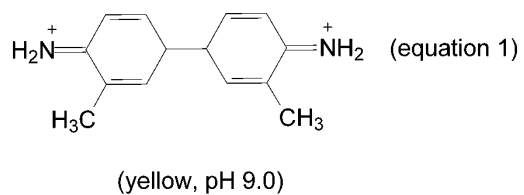

(yellow, $\mathrm{pH}$ 9.0)

Scheme 1. 


\section{Results and discussions}

Paracetamol exhibited significant reactivity with hypochlorite when exposed in large molar excess, leading to the production of multiple products such as 1,4-benzoquinone, N-acetyl-p-benzoquinoneimine and another products with molar mass higher than $300 \mathrm{~g} \mathrm{~mol}^{-1}[12,35]$.

The proposed flow injection system is based on the ability of oxidation of paracetamol by hypochlorite in excess at $\mathrm{pH} 9.0$ and the hypochlorite excess was monitored with $o$-tolidine producing a yellow diiminequinone at $\mathrm{pH} 9.0[12,38]$.

The chemical and flow injection parameters were optimized by univariated method in order to achieve a good compromise between the peak height, reproducibility, accuracy, precision, baseline stability and analytical frequency.

\section{Chemical parameters}

Preliminary studies to optimize chemical parameters were carried out using a manifold shown in Figure 1. In this flow system the hypochlorite and $o$-tolidine flow rates was $1.2 \mathrm{~mL} \mathrm{~min}^{-1}$ and that of carrier was $2.2 \mathrm{~mL} \mathrm{~min}^{-1}$, the sample loop of $100 \mu \mathrm{L}$, reaction coil length $\mathrm{RC}_{1}$ of $150 \mathrm{~cm}$ and reaction coil length $\mathrm{RC}_{2}$ of $60 \mathrm{~cm}$ were also used. Initially, the effect of hypochlorite concentration over the range from $2.4 \times 10^{-5}$ to $1.2 \times 10^{-4} \mathrm{~mol} \mathrm{~L}^{-1}$ on the analytical signal $(\Delta \mathrm{A})$ for a $9.4 \times 10^{-5} \mathrm{~mol} \mathrm{~L}^{-1}$ paracetamol solution, using a $9.8 \times 10^{-5} \mathrm{~mol} \mathrm{~L}^{-1} o$-tolidine in 0.22 mol $\mathrm{L}^{-1} \mathrm{HCl}$ solution was investigated. The analytical signal increased with increase of hypochlorite concentration up to $9.4 \times 10^{-5} \mathrm{~mol} \mathrm{~L}^{-1}$ and, remaining constant for higher concentrations. Thus, a $9.4 \times 10^{-5} \mathrm{~mol} \mathrm{~L}^{-1}$ hypochlorite solution was selected in further work.

The effect of $\mathrm{HCl}$ concentration in the $o$ tolidine solution on the peak high was studied from $4.4 \times 10^{-2}$ to $0.22 \mathrm{~mol} \mathrm{~L}^{-1}$ using a $9.4 \times 10^{-5}$ mol L-1 hypochlorite solution and $9.8 \times 10^{-5} \mathrm{~mol} \mathrm{~L}^{-}$ 1 o-tolidine solution. The analytical signal increased with increase of the $\mathrm{HCl}$ concentration up to $0.20 \mathrm{~mol} \mathrm{~L}^{-1}$ and remaining constant for higher concentrations. Thus, the $0.20 \mathrm{~mol} \mathrm{~L}^{-1} \mathrm{HCl}$ was selected for further work.

To study the effect of $\mathrm{pH}$ of hypochlorite solution, a $1.00 \times 10^{-2} \mathrm{~mol} \mathrm{~L}^{-1}$ borate buffer solution was employed. The study was performed over the
$\mathrm{pH}$ range from 7.0 to 11.4 . The analytical signal showed a slight increased with increase of $\mathrm{pH}$ up to $\mathrm{pH}$ 9.0. Higher $\mathrm{pH}$ promotes a severe interfere in the reaction between $\mathrm{ClO}^{-}$and $o$-tolidine decreasing the analytical signal due the consumption of $\mathrm{HCl}$ of the stream before the confluence point.

The effect of $o$-tolidine concentration on the analytical signal was investigated in the concentration range from $1.6 \times 10^{-5}$ to $1.2 \times 10^{-4} \mathrm{~mol}$ $\mathrm{L}^{-1}$. It was observed that the analytical signal increased with the increases of $o$-tolidine concentration up to $9.8 \times 10^{-5} \mathrm{~mol} \mathrm{~L}^{-1}$ remaining constant for higher $o$-tolidine concentrations. Furthermore, a $9.8 \times 10^{-5} o$-tolidine solution was selected for further studies.

\section{Flow injection parameters}

The effect of the coiled reactor $\left(\mathrm{RC}_{1}\right.$ and $\mathrm{RC}_{2}$ ) length on the analytical signal was studied from 30 to $150 \mathrm{~cm}$. In this study, it was observed that increasing the length of coiled reactor $\mathrm{RC}_{1}$ up to $75 \mathrm{~cm}$ promote a slight increase of analytical signal. For higher coiled reactor length the analytical signal decreased. Therefore, a $75 \mathrm{~cm}$ reactor length $\left(\mathrm{RC}_{1}\right)$ was selected. The effect of reactor coil $\mathrm{RC}_{2}$ length was studied over the same range, the signal showed best peak height using a $75 \mathrm{~cm}$ length. A reactor coil $\mathrm{RC}_{2}$ of $75 \mathrm{~cm}$ length was selected to further experiments.

The effect of sample volume from 100 to $600 \mu \mathrm{L}$ on peak height $(\Delta \mathrm{A})$ was studied for a 5.8 x $10^{-4} \mathrm{~mol} \mathrm{~L}^{-1}$ paracetamol reference solution. The analytical signal increased with increase of sample loop volume. Considering the repeatability and height of analytical signal, a $400 \mu \mathrm{L}$ sample loop length was selected.

The effect of flow rate for $o$-tolidine, hypochlorite and carrier (desionized water) on analytical signal was studied in the flow rates of 0.9 , 1.6 and $2.2 \mathrm{~mL} \mathrm{~min}^{-1}$, respectively. It was found that the analytical signal decreased deeply with the increasing of hypochlorite flow rate $\left(\mathrm{R}_{1}\right)$. Therefore, a flow rate of $0.9 \mathrm{~mL} \mathrm{~min}{ }^{-1}$ was selected for further experiments. In the $o$-tolidine flow rate $\left(R_{2}\right)$ study it was observed that the highest analytical signals were obtained for the $1.6 \mathrm{~mL} \mathrm{~min}^{-1}$ flow rate. This flow rate was selected as optimum. In the study of effect of carrier flow rate on the analytical signal showed that the flow rate of $2.2 \mathrm{~mL}$ 
$\min ^{-1}$ promotes the best analytical signal in terms of sensitivity and analytical frequency. Thus, a flow rate of $2.2 \mathrm{~mL} \mathrm{~min}^{-1}$ was selected in this work.

\section{Interferences and recovery studies}

The selectivity of the proposed flow injection procedure was studied comparing the analytical signal of a $1.5 \times 10^{-4} \mathrm{~mol} \mathrm{~L}^{-1}$ paracetamol standard solution with $1.5 \times 10^{-4} \mathrm{~mol} \mathrm{~L}^{-1}$ paracetamol reference solutions containing the commonly excipients found in commercial pharmaceutical formulations in the concentrations that cause a error of $\pm 5 \%$. The studied excipients were

Table 1. Recoveries of paracetamol standard solutions.

\begin{tabular}{|c|c|c|c|}
\hline Samples & $\begin{array}{l}\text { Added / } \\
10^{-4} \mathrm{~mol} \mathrm{~L}^{-1}\end{array}$ & $\begin{array}{l}\text { Founded / } \\
10^{-4} \mathrm{~mol} \mathrm{~L}^{-1}\end{array}$ & $\begin{array}{c}\text { Recovery / } \\
\%\end{array}$ \\
\hline \multirow[t]{3}{*}{ Cibalena ${ }^{\circledR}$} & 0.50 & 0.50 & 100 \\
\hline & 0.95 & 0.96 & 101 \\
\hline & 1.12 & 1.13 & 101 \\
\hline \multirow[t]{3}{*}{ Tylenol 500® } & 0.50 & 0.50 & 100 \\
\hline & 0.95 & 0.93 & 97.8 \\
\hline & 1.12 & 1.09 & 97.3 \\
\hline \multirow[t]{3}{*}{ Tyramol 750® } & 0.50 & 0.51 & 102 \\
\hline & 0.95 & 0.97 & 102 \\
\hline & 1.12 & 1.10 & 98.2 \\
\hline \multirow[t]{3}{*}{ Tylenol 750® } & 0.50 & 0.52 & 104 \\
\hline & 0.95 & 0.97 & 102 \\
\hline & 1.12 & 1.11 & 99.1 \\
\hline \multirow[t]{3}{*}{ Paracetamol 500® } & (B) 0.50 & 0.50 & 100 \\
\hline & 0.95 & 0.97 & 102 \\
\hline & 1.12 & 1.15 & 103 \\
\hline \multirow[t]{3}{*}{ Tylenol DC® } & 0.50 & 0.50 & 100 \\
\hline & 0.95 & 0.94 & 98.9 \\
\hline & 1.12 & 1.10 & 98.2 \\
\hline \multirow[t]{3}{*}{ Resfry® } & 0.50 & 0.50 & 100 \\
\hline & 0.95 & 0.94 & 98.9 \\
\hline & 1.12 & 1.10 & 98.2 \\
\hline \multirow[t]{3}{*}{ Paracetamol® } & 0.50 & 0.49 & 98.0 \\
\hline & 0.95 & 0.94 & 98.9 \\
\hline & 1.12 & 1.11 & 99.1 \\
\hline
\end{tabular}

$\mathrm{n}=3$. polivinylpirrolidine, citric acid, saccharine, tartrazine, caffeine, EDTA and sodium carboxymethylcellulose. Only the citric acid and caffeine showed high interference above an analyte:interference ratio of 1:10. Probably, these substances are oxidized by $\mathrm{ClO}^{-}$. But, the amounts of theses substances in the commercial pharmaceuticals are lower than that of paracetamol. The other excipients do not shown any interference at the same concentration of paracetamol.

The study of addition and recovery of paracetamol in pharmaceutical products was performed to verify the interference in potential of sample matrix. Tablets and syrups were employed. This study was performed spiking three aliquots of paracetamol standard solution in the concentrations of $5.00 \times 10^{-5} ; 9.50 \times 10^{-5}$ and $1.10 \times 10^{-4} \mathrm{~mol}$ $\mathrm{L}^{-1}$ in a sample solution containing $1.12 \times 10^{-4} \mathrm{~mol}$ $\mathrm{L}^{-1}$ paracetamol. Recoveries of paracetamol ranged from 97.3 to $103 \%$ as shown in Table 1. These results obtained suggested an absence of matrix effect on those determinations.

\section{Analytical features and application}

The flow injection procedure developed present an analytical curve linear in the paracetamol concentration range form $8.50 \times 10^{-6}$ to $2.51 \mathrm{x}$ $10^{-4} \mathrm{~mol} \mathrm{~L}^{-1}$ described by equation: $\Delta A=0.058+$ $1.571,41 \times C ; \mathrm{r}=0.9990$, where $\Delta A$ is $\left(\mathrm{A}_{1}-\mathrm{A}_{2}\right)$, the difference between the baseline absorbance $\left(\mathrm{A}_{1}\right)$ and the transient signal of solution injected containing paracetamol, and $C$ is the paracetamol concentration in $\mathrm{mol} \mathrm{L}^{-1}$.

The relative standard deviation (RSD) was lower than $1.2 \%(\mathrm{n}=10)$ for $1.20 \times 10^{-4} \mathrm{~mol} \mathrm{~L}^{-1}$ paracetamol solution and the detection limit obtained was $5.0 \times 10^{-6} \mathrm{~mol} \mathrm{~L}^{-1}$ (three times blank signal/inclination of analytical curve). The analytical frequency of 60 determinations per hour was obtained.

The paracetamol determination was performed using the developed spectrophotometric flow injection method and the results obtained were compared with those obtained using a USP Pharmacopoeia procedure [36]. As shown in Table 2 , the results obtained using the proposed flow injection procedure are in good agreement with those results obtained using the comparative procedure at confidence level of $95 \%$. 
Analytical features attained by the proposed flow procedure and those reported by described flow procedures with spectrophotometric detection are presented in Table 3 . The linear response was comparable with flow system were paracetamol was hydrolyzed before the detection [39] and higher than system described were paracetamol is monitored at an optode [18, 27]. The procedure proposed by Knochen et al. [17] uses a second degree polynomial analytical curve. The sampling rate was higher than procedures that have used alkaline hydrolysis and optode as sensor. The detection limit was better than previously reported by Burakham et al. [18],

Table 2. Determination of paracetamol in pharmaceutical products using the flow injection and the USP procedure [36].

\begin{tabular}{|c|c|c|c|}
\hline \multirow[t]{2}{*}{ Samples } & \multicolumn{2}{|c|}{ Paracetamol/mg g ${ }^{-1}$} & \multirow{2}{*}{$\begin{array}{c}\text { Relative } \\
\text { error } \\
(\mathrm{Er} / \%)\end{array}$} \\
\hline & USP & Proposed & \\
\hline Cibalena ${ }^{\circledR}$ & $300 \pm 5$ & $302 \pm 3$ & 0.7 \\
\hline Tylenol 500® & $850 \pm 4$ & $840 \pm 4$ & -1.2 \\
\hline Tyramol 750® & $860 \pm 6$ & $820 \pm 3$ & -4.6 \\
\hline Tylenol 750® & $850 \pm 7$ & $861 \pm 4$ & 1.3 \\
\hline Paracetamol 500® & $820 \pm 4$ & $868 \pm 3$ & 5.8 \\
\hline Tylenol DC® & $760 \pm 6$ & $771 \pm 2$ & 1.4 \\
\hline Resfry® & $410 \pm 5$ & $391 \pm 1$ & $-4,6$ \\
\hline Paracetamol®(*) & $198 \pm 6$ & $203 \pm 2$ & 2.5 \\
\hline
\end{tabular}

$\mathrm{n}=3$;

(*)mg L ${ }^{-1}$;

Er: FIA vs. USP procedure. but compare unfavorably with those obtained by Criado et al. [39] and by Cañada et al. [27]. However, these flow procedures have showed lower sampling rate.

The proposed flow system compare favorably with a chemiluminescence flow procedures described by Alapont et al. [29] and by Pulgarin and Bermejo [33], showing better precision and largest linear range.

\section{Conclusions}

The proposed flow procedure was suitable for the determination of paracetamol in pharmaceutical formulations, presenting accuracy and precision necessary to quality control laboratories. The paracetamol determination not requires extensive preliminary sample treatment. The procedure does not require expensive reagents and can be implemented easily in pharmaceutical laboratories. This procedure is simpler than spectrofluorimetric procedure described by Vilchez et al. [12] due the use of a suitable spectrophotometer.

\section{Acknowledgements}

The scholarship granted to H.J.V. from CAPES is gratefully acknowledged.

Received 08 February 2008

Accepted 28 May 2008

Table 3. Analytical features of spectrophotometric flow procedures for paracetamol determination in pharmaceuticals.

\begin{tabular}{cccccc}
\hline & {$[17]$} & {$[18]$} & {$[27]$} & {$[39]$} & Proposed \\
\hline $\begin{array}{c}\text { Linearity/ } \\
10^{-4} \mathrm{~mol} \mathrm{~L}^{-1}\end{array}$ & 1.2 to 198 & $\begin{array}{c}26.4 \text { to } 66.1 \\
\text { or } \\
\mathrm{RSD} / \%\end{array}$ & 0.03 to 0.5 & 0.04 to 1.3 & 0.085 to 2.5 \\
$\left(\mathrm{~mol} \mathrm{~L}^{-1}\right)$ & $<1.3$ & 2 & 1.24 & 1.8 & 1.2 \\
$\begin{array}{c}\text { Detection limit/ } \\
10^{-5} \mathrm{~mol} \mathrm{~L}^{-1}\end{array}$ & a & 29.7 & $1.45 \times 10^{-2}$ & 0.13 & 0.5 \\
Analytical frequency & 120 & 60 & 40 & 20 & 60 \\
\hline
\end{tabular}

${ }^{a}$ not reported. 
O. F. Filho, H. J. Vieira. Método de análise por injeção em fluxo para determinação indireta de paracetamol em formulações farmacêuticas empregando o-tolidina como reagente.

Resumo: Um procedimento de injeção em fluxo com detecção espectrofotométrica para a determinação de paracetamol foi descrito. O procedimento foi baseado na reação de oxidação do paracetamol pelo hipoclorito de sódio e a determinação de seu excesso empregando o dicloreto de o-tolidina como reagente cromogênico. A curva analítica apresentou um comportamento linear entre as concentrações de paracetamol de $8,5 \times 10^{-6}$ a 2,51 x 10-4 mol L-1 com um limite de detecção de 5,0 x 10-6 mol L-1. O desvio padrão relativo foi menor que $1,2 \%$ para uma solução de paracetamol de $1,20 \times 10^{-4} \mathrm{~mol} \mathrm{~L}^{-1}(\mathrm{n}=10)$. Os resultados obtidos nas análises de produtos farmacêuticos comerciais obtidos empregando o procedimento desenvolvido foram comparados com aqueles obtidos empregando o procedimento descrito na Farmacopéia Americana (USP XXII) estando em concordância ao nível de confiança de $95 \%$.

Palavras-chave: Paracetamol; produtos farmacêuticos; análise por injeção em fluxo; espectrofotometria.

\section{References}

[1] L.S. Goodman, A. Gilman, Bases Farmacológicas de la Terapêutica, 4 edition, New York, Interamericana, 1974.

[2] F.D. Fuchs, L. Wannmacher, Farmacologia Clínica Fundamentos da Terapêutica Racional, 2 ed., Rio de Janeiro, Guanabara Koogan, 1999.

[3] E. Dinc, C. Yucesoy, F. Onur, J. Pharm. Biomed. Anal. 28 (2002) 1091.

[4] S.D. Cekic, H. Filik, R. Apak, J. Anal. Chem. 60 (2005) 1019. [5] A. Afkhami, N. Sarlak, Acta Chim. Slov. 52 (2005) 98.

[6] P. Nagaraja, K.C.S. Murthy, K.S. Rangappa, J. Pharm. Biomed. Anal. 17 (1998) 501.

[7] J.S.E. Romero, L.A. Rodriguez, M.C.G. Alvarezcoque, G. Ramisramos, Analyst 119 (1994) 1381.

[8] R.N. Rao, A. Narasaraju, Anal. Sci. 22 (2006) 287.

[9] L. Monser, F. Darghouth, J. Pharm. Biomed. Anal. 27 (2002) 851.

[10] M. Gil-Agusti, L. Monferrer-Pons, M.C. Garcia-AlvarezCoque, J. Esteve-Romero, Talanta 54 (2001) 621.

[11] A.B. Moreira, H.P.M. Oliveira, T.D.Z. Atvars, I.L.T. Dias, G.O. Neto, E.A.G. Zagatto, L.T. Kubota, Anal. Chim. Acta 539 (2005) 257.

[12] J.L. Vilchez, R. Blanc, R. Avidad, A. Navalon, J. Pharm. Biomed. Anal. 13 (1995) 1119.

[13] I.C. Vieira, K.O. Lupetti, O. Fatibello-Filho, Quim. Nova 26 (2003) 39.

[14] C.Y. Wang, X.Y. Hu, Z.Z. Leng, G.J. Yang, G.D. Jin, Anal. Lett. 34 (2001) 2747.

[15] O. Fatibello-Filho, K.O. Lupetti, I.C. Vieira, Talanta 55 (2001) 685.

[16] J. Martínez-Calatayud, Flow Injection Analysis of Pharmaceuticals - Automation in Laboratory, 1 ed., Taylor \& Francis Inc., 1996.

[17] M. Knochen, J. Giglio, B.F. Reis, J. Pharm. Biomed. Anal. 33 (2003) 191.

[18] R. Burakham, S. Duangthong, L. Patimapornlert, N. Lenghor, S. Kasiwad, L. Srivichai, S. Lapanantnoppakhun, J. Jakmunee, K. Grudpan, Anal. Sci. 20 (2004) 837.

[19] W.T. Suarez, H.J. Vieira, O. Fatibello-Filho, Ecl. Quim. 30 (2005) 21.
[20] Z. Bouhsain, S. Garrigues, A. Morales-Rubio, M. de la Guardia, Anal. Chim. Acta 330 (1996) 59.

[21] A. Criado, S. Cardenas, M. Gallego, M. Valcarcel, Analyst 125 (2000) 1179.

[22] C. Aniceto, O. Fatibello-FIlho, Quim. Nova 25 (2002) 387.

[23] F. Priego-Capote, M.D.L. de Castro, Anal. Chim. Acta 489 (2003) 223

[24] A.F. Lavorante, C.K. Pires, B.F. Reis, J. Pharm. Biomed. Anal. 42 (2006) 423.

[25] A.R. Medina, M.L.F. de Cordova, A.M. Diaz, Anal. Chim. Acta 394 (1999) 149.

[26] A. Ruiz-Medina, M.L. Fernandez-de Cordova, M.J. Ayora-Canada, M.I. Pascual-Reguera, A. Molina-Diaz, Anal. Chim. Acta 404 (2000) 131.

[27] M.J.A. Cañada, M.I.P. Reguera, A.R. Medina, M.L.F. de Cordova, A.M. Diaz, J. Pharm. Biomed. Anal. 22 (2000) 59.

[28] P. Ortega-Barrales, R. Padilla-Weigand, A. Molina-Diaz, Anal. Sci. 18 (2002) 1241.

[29] A.G. Alapont, L.L. Zamora, J.M. Calatayud, J. Pharm. Biomed. Anal. 21 (1999) 311.

[30] D. Easwaramoorthy, Y.C. Yu, H.J. Huang, Anal. Chim. Acta 439 (2001) 95.

[31] W. Ruengsitagoon, S. Liawruangrath, A. Townshend, Talanta 69 (2006) 976.

[32] M.L. Ramos, J.F. Tyson, D.J. Curran, Anal. Chim. Acta 364 (1998) 107.

[33] J.A.M. Pulgarin, L.F.G. Bermejo, Anal. Chim. Acta 333 (1996) 59.

[34] M.E. Bosch, A.J.R. Sánchez, F.S. Rojas, C.B. Ojeda, J. Pharm. Bomed. Anal. 42 (2006) 291.

[35] M. Bedner, W.A. Maccrehan, Environ. Sci. Tech. 40 (2006) 516.

[36] USP, United States Pharmacopeial XXII, Rockville, MD, U.S Pharmacopeial Convention, 1990.

[37] B.F. Reis, H. Bergamin-Filho, Quim. Nova 16 (1993) 570.

[38] J.D. Johnson, R. Overby, Anal. Chem. 41 (1969) 1744.

[39] A. Criado, S. Cardenas, M. Gallego, M. Valcarcel, Talanta 53 (2000) 417. 